\title{
Miller-Dieker syndrome with ring chromosome 17
}

\author{
N Sharief, J Craze, D Summers, L Butler, C B S Wood
}

\begin{abstract}
A girl presented at 6 weeks of age with failure to thrive and arching of the back. She had various dysmorphic features, hepatosplenomegaly, and developmental delay. The electroencephalogram and cranial ultrasound were abnormal, and a computed tomogram showed lissencephaly and apparent agenesis of the corpus callosum. Because of frequent aspiration she became oxygen dependent. She later developed intractable convulsions and died at the age of 9 months.
\end{abstract}

Miller described two and Dieker et al described four infants all of whom had microcephaly, developmental delay, hypotonia, opisthotonos, micrognathia, ear anomalies, and lissencephaly. ${ }^{12}$ Other non-consistent features included seizures, bitemporal grooving of a high forehead, anteverted nares, cardiac defects, and undescended testes. The eponym Miller-Dieker syndrome was proposed by Jones et al. ${ }^{3}$

Dobyns et al described three patients and reviewed five additional patients from the literature, all of whom had Miller-Dieker syndrome and an abnormality of $17 \mathrm{p} .{ }^{4}$ They proposed that monosomy of distal $17 p$ may be the cause of Miller-Dieker syndrome in some patients. Ono et al were the first to describe a child with a ring chromosome $17 .^{5}$ Four further cases with ring chromosome 17 have since been reported, 6-8 and two of them had features in common with Miller-Dieker syndrome including lissencephaly. ${ }^{4}$

We describe another infant who had features of both Miller-Dieker syndrome and ring chromosone 17 phenotype.

Queen Elizabeth Hospital for Children,

Hackney Road,

London E2 8PS

Department of

Child Health

N Sharief

J Craze

C B S Wood

Department of

Cytogenetics

D Summers

L Butler

Correspondence to:

Dr N Sharief,

Basildon Hospital,

Basildon,

Essex SS16 5NL.

Accepted 27 December 1990

\section{Case report}

A girl, the second child of healthy unrelated parents, was born at full term at home by normal vaginal delivery. She had been found to be small for dates on ultrasound scan at 17 weeks and this was confirmed on a further scan at 39 weeks. Her birth weight was $2270 \mathrm{~g}$. There were no neonatal problems and she was totally breast fed.

At 6 weeks of age she was referred to hospital because of failure to gain weight and attacks of arching her back and screaming, mostly during feeds. Examination showed a dysmorphic child (fig 1) whose weight, length, and head circumference were below the 3rd centile for age. Her eyes were widely set and the palpebral fissures slanted downwards. Her ears were rotated posteriorly, the nasal bridge was low, the nose was

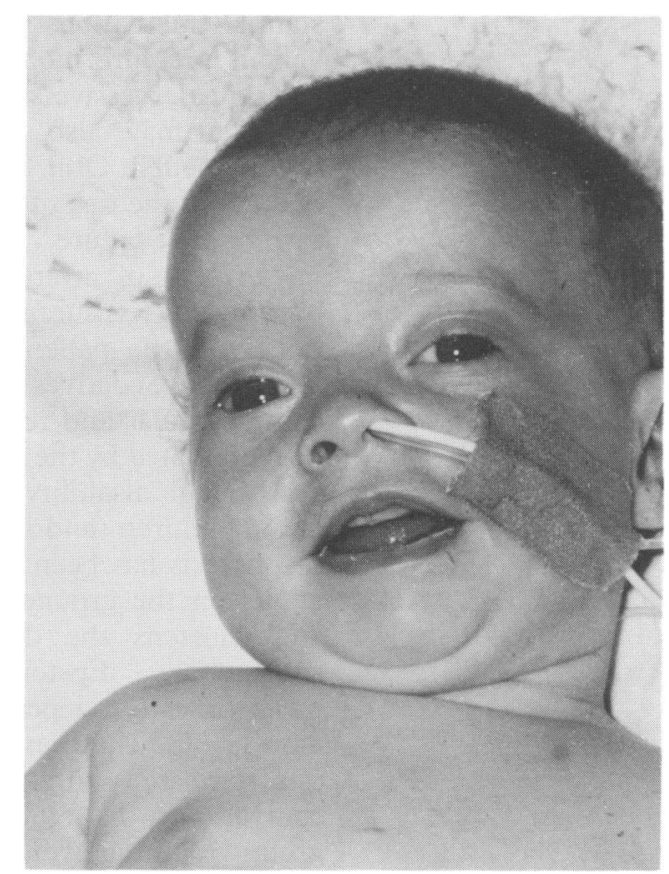

Figure 1 Facial appearance of the present case.

small with anteverted nostrils, and the jaw was also small. She had clinodactyly and abnormal palmar creases but her dermatoglyphics were normal. Her spleen was $2.5 \mathrm{~cm}$ below the costal margin and her liver was palpable $2 \mathrm{~cm}$ below the costal margin. She was generally hypotonic, she arched her back periodically, and she did not seem to follow light or objects although her corneas were clear.

Cranial ultrasonography showed bilateral dilatation of the posterior horns of the lateral ventricles. A computed tomogram showed lissencephaly and apparent agenesis of the corpus callosum (fig 2). An electroencephalogram showed pronounced abnormalities with runs of large amplitude rhythmic slow and intermediate slow activities, particularly in the anterior regions. There were no clear focal signs or paroxysmal features. Contrast radiographic examination with propyliodine showed gross nasal escape and aspiration on swallowing, indicating pharyngeal incoordination. She continued to feed well by bottle, albeit with frequent attacks of aspiration, until she was 16 weeks old and then required nasogastric feeding. She had difficulty in swallowing her saliva and required frequent suction of her oropharynx. Secondary to frequent aspiration she developed chronic lung disease and was oxygen dependent from the age of 25 weeks. She continued to gain weight and at 8 months of 


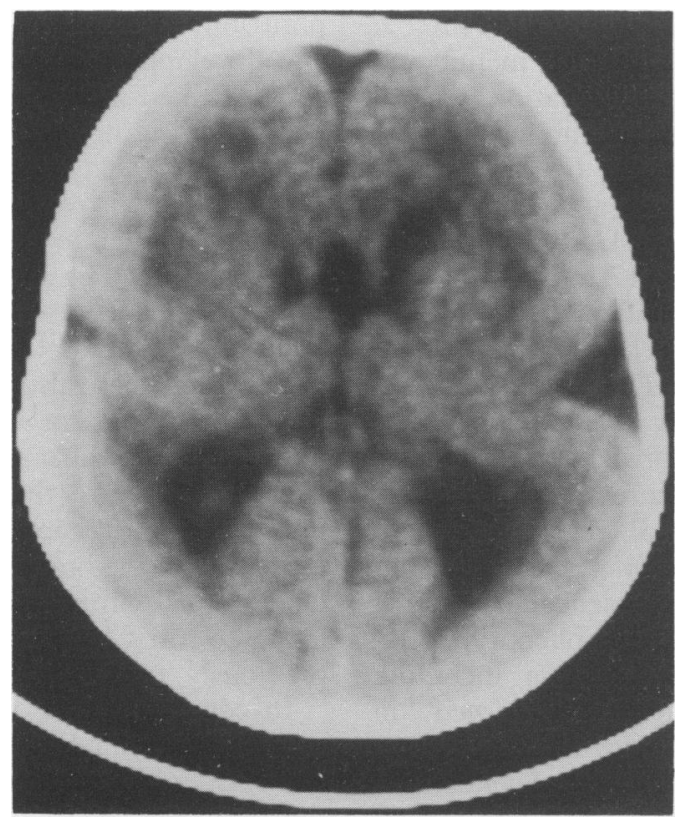

Figure 2 Computed tomogram showing a smooth cortex with absence of normal gyral pattern (lissencephaly). The lateral ventricles are widely separated with the third ventricle reaching up in between them suggesting agenesis or hypoplasia of the corpus callosum.

age was just below the third centile. She developed a divergent squint but examination of the eyes, including the corneas and fundoscopy, was normal. Her development remained static, compatible with that of a floppy newborn baby. Her convulsions started at 15 weeks of age and progressed with increasing frequency in spite of treatment with different anticonvulsants. She developed cafe au lait spots at 6 months. At 8 months her fits became intractable, and she died when she was 9 months old.

At postmortem examination there were signs of bronchopneumonia. The brain was small and agyric with a thin corpus callosum. The cortical ribbon was three times the normal thickness, the white matter was meagre, and within it were numerous nodular grey heterotopias surrounding the ventricles. Other features were small frontal and large occipital horns, dentate dysplasia and grey heterotopias in the cerebellum, and inferior olivary heterotopia in the medulla.

\section{CYTOGENETIC STUDIES}

Standard chromosome preparations were obtained from short term cultures of lymphocytes stimulated with phytohaemagglutinin in Iscove's medium. Higher banding resolution was achieved by incorporating ethidium bromide into the culture medium and exposing the slides briefly to trypsin before Giemsa staining in the usual way.

The chromosome count was 46 with a karyotype in which one of the chromosomes 17 was replaced by a ring structure $(46, \mathrm{XX}$, (r) (17)). The size of the ring and the relative position of bands $\mathrm{q} 24.3$ and p12 indicated that the break points were probably at p13.1 and $\mathrm{q} 25.3$ prior to the fusion leading to the ring formation (fig 3). There is thus a terminal deletion of both long and short arms, the short arm de-

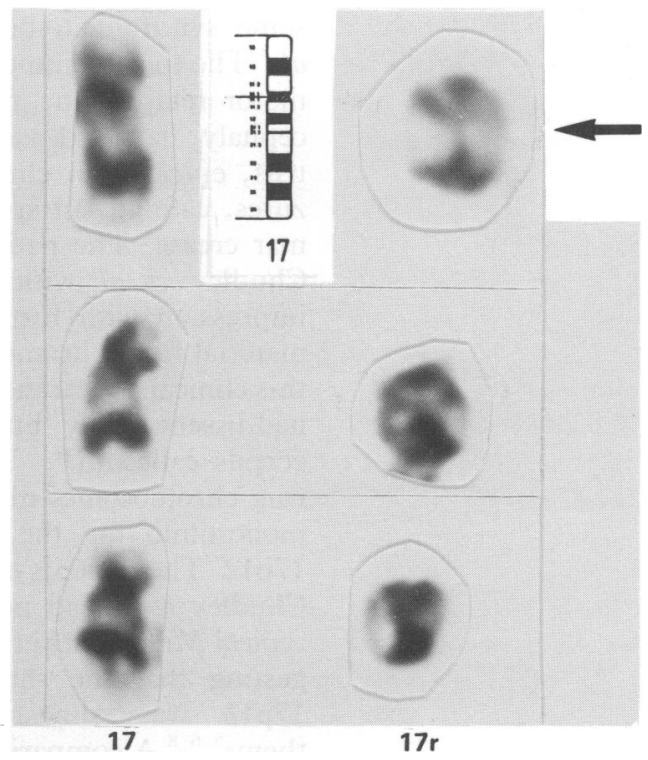

Figure 3 Homologues of chromosome 17 from three cells. The arrow indicates the site of union of the short and long arms in the ring formation, indicating only a small terminal deletion of each arm.

letion being of equivalent size to that found in the Miller-Dieker syndrome. The karyotypes of both parents were normal.

\section{Discussion}

Stratton et al reviewed the cytogenetics of the 11 reports of Miller-Dieker syndrome: nine showed monosomy for the terminal region of $17 p$ down to band p13. ${ }^{9}$ No deletion was present in one (case 2 reported by Dobyns et $a l^{4}$ ), and in another family (Norman et al ${ }^{10}$ ) where parental chromosomes were normal, the affected subjects did not have the typical Miller-Dieker syndrome facies. ${ }^{9}$ To the above nine cases can be added the 12 year old boy with typical facies and terminal $17 p$ deletion reported recently by Selypes and Laszlo. ${ }^{11}$ In this case lissencephaly was also shown on the computed tomogram. Stratton et al concluded from the extent of the various deletions for $17 p$ that the critical region for Miller-Dieker syndrome is the sub band p13.3.9 More recently, application of DNA probes has provided substantial evidence to support this. Schwartz et al, and Van Tuinen et $a l$, have shown that there are submicroscopic deletions of this sub band in patients with Miller-Dieker syndrome who were previously thought to have had normal chromosomes. ${ }^{12} 13$

There are to our knowledge five previous reports of liveborn patients with non-mosaic ring chromosome $17 .{ }^{4-8}$ The 20 week fetus with $r$ (17) described by Weinberg et al and the 4 year old girl with mental retardation and growth failure found to be a mosaic $46 \mathrm{XX} / 46 \mathrm{XX}, \mathrm{r}(17)$ by Petit and Koulischer are excluded from this discussion. ${ }^{14} 15$ In addition, the report by Burdea et al (who described a father and son with apparent ring chromosome 17, the son being microcephalic and with mental retardation) will not be considered here as the identity of the chromosome was not confirmed by banding. ${ }^{16}$

These five patients had enough clinical abnormalities in common for a 'ring 17 chromo- 
some' syndrome to be proposed by Carpenter $e t$ $a l .{ }^{7}$ The most common features are mental and motor retardation, growth retardation, microcephaly, flattened nasal bridge, anteverted nostrils, epicanthus, clinodactyly, hypotonia, seizures, cafe au lait spots, and a transverse palmar crease. The patients of Dobyns et al and Chudley et al with ring 17 reinforced this impression with further evidence that loss of material from chromosome 17 was the cause of this clinical appearance. ${ }^{48}$ Two of the cases also had lissencephaly, but only one had a defective corpus callosum. ${ }^{7}$ The break points in their ring chromosomes must therefore render them monosomic for the critical region distal to 17p12. The patients of Ono et al, Qazi et al, and Chudley et al had neither lissencephaly nor a typical Miller-Dieker syndrome phenotype suggesting that the short arm region including $17 \mathrm{p} 13$ was almost entirely preserved in them. ${ }^{568} \mathrm{~A}$ comparison of the clinical features of ring 17 phenotype and Miller-Dieker syndrome is shown in table 1 , together with the clinical details of the present case.

Our patient exhibited features of both ring chromosome 17 (psychomotor and growth retardation, microcephaly, flat nasal bridge, anteverted nares, fits and cafe au lait patches), and of Miller-Dieker syndrome (lissencephaly, antenatal and postnatal growth retardation, bitemporal hollowing, anteverted nares, long

Comparison of clinical features of present case, Miller-Dieker syndrome, and ring chromosome 17

\begin{tabular}{|c|c|c|c|}
\hline Clinical features & $\begin{array}{l}\text { Miller-Dieker } \\
\text { syndrome }\end{array}$ & $\begin{array}{l}\text { Ring } \\
\text { chromosome } \\
17\end{array}$ & $\begin{array}{l}\text { Present } \\
\text { case }\end{array}$ \\
\hline $\begin{array}{l}\text { Growth retardation } \\
\text { Mental retardation } \\
\text { Microcephaly } \\
\text { Lissencephaly } \\
\text { Prominent occiput } \\
\text { Narrow forehead/excessive } \\
\text { wrinkled skin } \\
\text { Hypertelorism } \\
\text { Epicanthus } \\
\text { Palpebral fissures slanting } \\
\text { downwards } \\
\text { Ptosis } \\
\text { Divergent squint } \\
\text { Clouded cornea } \\
\text { Small nose } \\
\text { Broad nasal bridge } \\
\text { Prominent bulbous nose } \\
\text { Anteverted nostrils } \\
\text { Puckered lips } \\
\text { Malformed ears } \\
\text { Ears rotated posteriorly } \\
\text { Micrognathia } \\
\text { High arched palate } \\
\text { Widely spaced nipples } \\
\text { Arachnodactyly } \\
\text { Low set thumbs } \\
\text { Polydactyly } \\
\text { Coxa vara } \\
\text { Abnormal palmar creases } \\
\text { Cafe au lait spots } \\
\text { Hirsutism } \\
\text { Hypotonia } \\
\text { Seizures } \\
\text { Heart defect } \\
\text { Renal defect }\end{array}$ & $\begin{array}{l}\text { Yes } \\
\text { Yes } \\
\text { Yes } \\
\text { Yes } \\
\text { Yes } \\
\text { Yes } \\
\text { Yes } \\
\text { No } \\
\text { Yes } \\
\text { Yes } \\
\text { No } \\
\text { Yes } \\
\text { Yes } \\
\text { No } \\
\text { No } \\
\text { Yes } \\
\text { Yes } \\
\text { Yes } \\
\text { Yes } \\
\text { No } \\
\text { No } \\
\text { No } \\
\text { No } \\
\text { No } \\
\text { Yes } \\
\text { No } \\
\text { No } \\
\text { No } \\
\text { Yes } \\
\text { Yes } \\
\text { Yes } \\
\text { Yes } \\
\text { Yes }\end{array}$ & $\begin{array}{l}\text { No } \\
\text { No } \\
\text { No } \\
\text { No } \\
\text { No } \\
\text { Yes } \\
\text { Yes } \\
\text { Yes } \\
\text { No } \\
\text { Yes } \\
\text { No } \\
\text { Yes } \\
\text { Yes } \\
\text { Yes } \\
\text { Yes } \\
\text { Yes } \\
\text { No } \\
\text { Yes } \\
\text { Yes } \\
\text { Yes } \\
\text { Yes } \\
\text { Yes } \\
\text { Yes } \\
\text { Yes } \\
\text { No }\end{array}$ & $\begin{array}{l}\text { Yes } \\
\text { No } \\
\text { Yes } \\
\text { No } \\
\text { Yes } \\
\text { Yes } \\
\text { No } \\
\text { Yes } \\
\text { Yes } \\
\text { Yes } \\
\text { Yes } \\
\text { Yes } \\
\text { No } \\
\text { No } \\
\text { No } \\
\text { No } \\
\text { No } \\
\text { No } \\
\text { Yes } \\
\text { Yes } \\
\text { No } \\
\text { Yes } \\
\text { Yes } \\
\text { No } \\
\text { No }\end{array}$ \\
\hline
\end{tabular}

philtrum, thin upper lip, micrognathia, fits, and developmental delay). Chromosome analysis confirmed the presence of $r(17)$ with breakpoints indicating that she was monosomic for the Miller-Dieker syndrome critical region $17 \mathrm{p} 13 \cdot 3$. She also had hypoplasia of the corpus callosum similar to cases 1 and 3 reported by Dobyns et al. ${ }^{4}$ The agenesis of the corpus callosum has been reported in a girl with partial deletion of distal $17 q .{ }^{17}$ Our patient and case 1 of Dobyns et al were also monosomic for distal $17 \mathrm{q}$ but case 3 of Dobyns et al with t(7:17) translocation was not, as the $\mathrm{q}$ arm was not affected. ${ }^{4}$ It is unlikely therefore that monosomy $17 q$ is the only determining factor for this congenital malformation of the brain. Our patient had nodular heterotopia within the white matter and bilateral olivary heterotopia of the medulla, as previously reported. 1210

In conclusion, we have presented a case in which the features of Miller-Dieker syndrome and $r(17)$ were present. As far as we know it is the first case reported from the United Kingdom.

We thank Dr Brian Harding, department of histopathology, Hospital for Sick Children, for undertaking the neuropathological examination, and Mrs Gloria Parkin for preparing the manuscript.

1 Miller JQ. Lissencephaly in two siblings. Neurology 1963;13 $841-50$

2 Dieker H, Edwards RH, ZuRein G, Chou SM, Hartman HA Opitz JM. The lissencephaly syndrome. Birth Defects 1969 5:53-64.

3 Jones KL, Gilbert EF, Kaveggia EG, Opitz IM. The MillerDieker syndrome. Pediatrics 1980;66:277-81.

4 Dobyns WB, Stratton RF, Parke JT, Greenberg F, Nussbaum RL, Ledbetter DH. The Miller-Dieker syndrome: lissencephaly and monosomy $17 \mathrm{p} . \mathcal{F}$ Pediatr 1983 ; 102:552-8.

5 Ono K, Suzuki Y, Fujii I, Takeshita K, Arima M, Nagakome Y. A case of ring chromosome E-17:46XXr(17) (p13-q25) Y. A case of ring chromosome E-17:46XXr(17)(pl3-q25).

6 Qazi QH, Madahar C, Kanchanapoomi R, Giridharan R, Beller E. Ring chromosome 17 in a mentally retarded boy. Ann Genet (Paris) 1979;22:234-8.

7 Carpenter NJ, Leichtman LG, Stamper S, Say B. An infant with ring 17 chromosome and unusual dermatoglyphics: a new syndrome? 7 Med Genet 1981;18:234-6.

8 Chudley AE, Pabello PD, McAlpine PJ, Nickel BE, Shokei MHK. Ring chromosome 17 in a mentally retarded young man-clinical, cytogenic and biochemical investigations. Am $\mathcal{F}$ Med Genet 1982;12:219-25.

9 Stratton RF, Dobyns WB, Airhart Susan D, Ledbetter DH. New chromosomal syndrome: Miller-Dieker syndrome and monosomy 17pl3. Hum Genet 1984;67:193-200.

10 Norman MG, Roberts $M$, Sirios J, Tremblay LJM. Lissencephaly. Can f Neurol Sci 1976;3:39-46.

11 Selypes A, Laszlo A. Miller-Dieker syndrome and monosomy 17p13: a new case. Hum Genet 1988;80:103-4.

12 Schwartz CE, Johnson JP, Holycross B, et al. Detection of submicroscopic deletions in band $17 \mathrm{pl} 3$ in patients with Miller-Dieker syndrome. Am f Hum Genet 1988;43: 597-604.

13 VanTuinen P, Dobyns WB, Rich DC, et al. Molecular detection of microscopic and submicroscopic deletions associated with the Miller-Dieker syndrome. Am F Hum Genet 1988 43:587-96.

14 Weinberg AG, Bair JL, Harrod MJ. Ring chromosome 17 detected by amniocentesis. Humangenetik 1975;28:269-72.

5 Petit K, Koulischer L. Etude d'une mosaique 46XX 46XX17r. Ann Genet (Paris) 1971;14:55-8.

16 Burdea M, Lupascu E, Margineanu L. Un caz familial de chromozom din grupa e in inel (17) $\mathrm{r}$ cu transmitere de tata la fiu. Rev Med Chir Soc Med Nat Iasi 1973;77:353-7.

17 Bridge J, Sanger W, Mosher G, et al. Partial deletion of distal 17q. Am F Med Genet 1985;21:225-9. 